\title{
Repurposing a Hindcast Simulation of the 1926 Great Miami Hurricane, South Florida
}

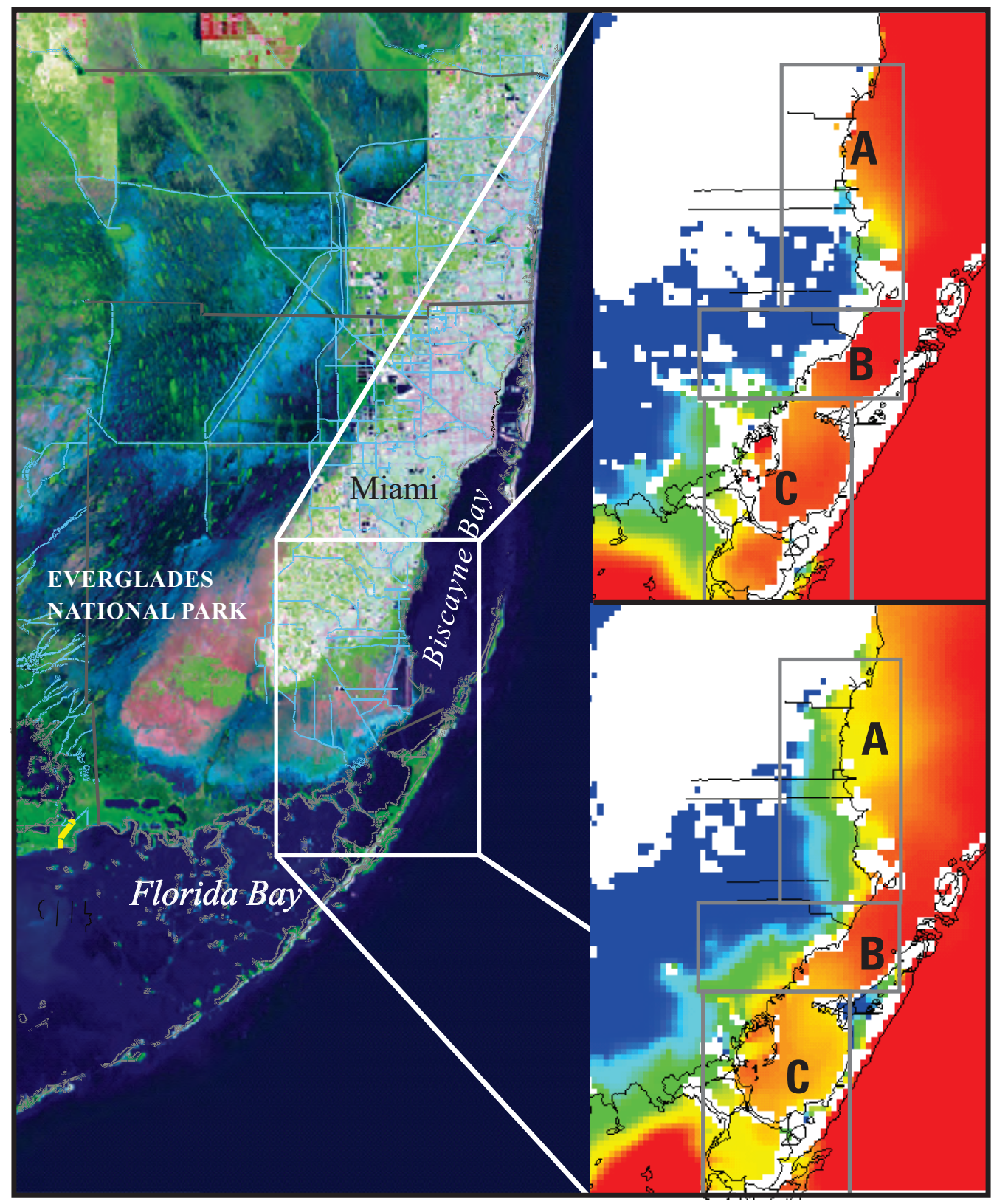

Open-File Report 2020-1010 



\section{Repurposing a Hindcast Simulation of the 1926 Great Miami Hurricane, South Florida}

By M. Dennis Krohn, Eric D. Swain, Catherine A. Langtimm, and

Jayantha Obeysekera

Open-File Report 2020-1010

U.S. Department of the Interior

U.S. Geological Survey 


\title{
U.S. Department of the Interior \\ DAVID BERNHARDT, Secretary
}

\author{
U.S. Geological Survey \\ James F. Reilly II, Director
}

U.S. Geological Survey, Reston, Virginia: 2020

For more information on the USGS - the Federal source for science about the Earth, its natural and living resources, natural hazards, and the environment—visit https://www.usgs.gov or call 1-888-ASK-USGS.

For an overview of USGS information products, including maps, imagery, and publications, visit https://store.usgs.gov/.

Any use of trade, firm, or product names is for descriptive purposes only and does not imply endorsement by the U.S. Government.

Although this information product, for the most part, is in the public domain, it also may contain copyrighted materials as noted in the text. Permission to reproduce copyrighted items must be secured from the copyright owner.

Suggested citation:

Krohn, M.D., Swain, E.D., Langtimm, C.A., and Obeysekera, J., 2020, Repurposing a hindcast simulation of the 1926 Great Miami Hurricane, south Florida: U.S. Geological Survey Open-File Report 2020-1010, 9 p., https://doi.org/ 10.3133/ofr20201010.

Associated data for this publication:

Swain, E.D., 2020, FTLOADDS (combined SWIFT2D surface-water model and SEAWAT groundwater model) simulator used to repurpose a hindcast simulation of the 1926 Great Miami Hurricane using the south Florida peninsula for the Biscayne and Southern Everglades Coastal Transport (BISECT) model: U.S. Geological Survey data release, https://doi.org/10.5066/P9C681IV.

ISSN 2331-1258 (online) 


\section{Contents}

Abstract
Introduction.
Methods
Previous Simulations
Results
Discussion
Summarisons of Storm Effects in Different Simulation Periods
Acknowledgments
References.

\section{Figures}

1. Map showing the study area including Everglades National Park, Ten Thousand Islands, and the eastern coastal area.

2. Map showing the canal system and topography in the BISECT model area in 1926 and 1996, south Florida

3. Maps showing salinity and inundation in areas $A, B$, and $C$ before and after the hindcast inland system and hindcast sea-level simulation; recent inland system and recent sea-level simulation; and hindcast inland system and recent sea-level simulation, south Florida

4. Graphs showing inundation and salinity before and after the simulated Great Miami Hurricane of 1926, south Florida.

\section{Table}

1. Changes in inundation and salinity in three areas before and after the simulated Great Miami Hurricane of 1926, south Florida

\section{Conversion Factors}

International System of Units to Inch/Pound

\begin{tabular}{lll}
\hline \multicolumn{1}{c}{ Multiply } & \multicolumn{1}{c}{ By } & \multicolumn{1}{c}{ To obtain } \\
\hline centimeter $(\mathrm{cm})$ & Length & \\
meter $(\mathrm{m})$ & 0.3937 & inch (in.) \\
kilometer $(\mathrm{km})$ & 3.281 & foot (ft) \\
\hline \multicolumn{2}{c}{ Area } & mile (mi) \\
\hline square meter $\left(\mathrm{m}^{2}\right)$ & 0.6214 & acre \\
square kilometer $\left(\mathrm{km}^{2}\right)$ & 247.1 & acre \\
\hline
\end{tabular}




\section{Datum}

Vertical coordinate information is referenced to the North American Vertical Datum of 1988 (NAVD 88).

Horizontal coordinate information is referenced to the North American Datum of 1983 (NAD 83).

Elevation, as used in this report, refers to distance above the vertical datum.

\section{Abbreviations}

$\begin{array}{ll}\text { BISECT } & \text { Biscayne and Southern Everglades Coastal Transport } \\ \text { CERP } & \text { Comprehensive Everglades Restoration Plan } \\ \text { ET } & \text { Evapotranspiration } \\ \text { FTLOADDS Flow and Transport in a Linked Overland/Aquifer Density-Dependent System } \\ \text { GMH } & \text { Great Miami Hurricane } \\ \text { HH } & \text { Hindcast hydrology and hindcast sea level } \\ \text { HR } & \text { Hindcast hydrology and recent sea level } \\ \text { PSU } & \text { Practical salinity units } \\ \text { RR } & \text { Recent hydrology and recent sea level } \\ \text { SLR } & \text { Sea-level rise } \\ \text { TIME } & \text { Tides and Inflows in the Mangroves of the Everglades } \\ \text { TTI } & \text { Ten Thousand Islands } \\ \text { USGS } & \text { U.S. Geological Survey }\end{array}$




\title{
Repurposing a Hindcast Simulation of the 1926 Great Miami Hurricane, South Florida
}

\author{
By M. Dennis Krohn, ${ }^{1}$ Eric D. Swain, ${ }^{1}$ Catherine A. Langtimm,1 and Jayantha Obeysekera ${ }^{2}$
}

\begin{abstract}
Hydrodynamic model hindcasts of the surface water and groundwater of the Everglades and the greater Miami, Florida, area were used to simulate hydrology using estimated storm surge height, wind field, and rainfall for the Great Miami Hurricane (GMH), which struck on September 18, 1926. Ranked estimates of losses from hurricanes in inflationadjusted dollars indicate that the GMH was one of the most damaging tropical cyclones to make landfall in the United States, but little hydrologic data were collected because many types of field stations did not exist at the time. Several techniques were used to estimate previously unknown critical storm variables for model input, demonstrating the value of reanalyzing historical storm events using modern hydrodynamic modeling. This representation of the $1926 \mathrm{GMH}$ was then used to develop a hypothetical simulation of the hydrologic effects of a similar hurricane occurring in contemporary (1996) times. Results indicate that the 18-centimeter sea-level rise between 1926 and 1996 had a greater effect on salinity intrusion than climatic differences or the development of modern canal-based infrastructure. Moreover, the post-1926 canal infrastructure does not seem to substantially mitigate the deleterious effects of sea-level rise.
\end{abstract}

\section{Introduction}

The U.S. Geological Survey (USGS) has developed a coupled hydrodynamic surface-water and groundwater simulator to improve understanding of the complex and interconnected hydrology in south Florida. This simulator, which is a combination of a pre-existing two-dimensional hydrodynamic surface-water code and a three-dimensional groundwater code, both with salinity transport (Langevin and others, 2005), is referred to as Flow and Transport in a Linked Overland/Aquifer Density-Dependent System (FTLOADDS).

1U.S. Geological Survey.

${ }^{2}$ Florida International University.
FTLOADDS provides a tool to examine the important surfacewater, groundwater, and coastal saline-water interactions prevalent in south Florida.

FTLOADDS has been applied to locations in Everglades National Park (Wang and others, 2007), Ten Thousand Islands (Swain and Decker, 2009), and the Biscayne Bay coastal urban area (Lohmann and others, 2012; fig. 1). The hydrologic conditions simulated by these models have been used in numerous ecologic models and analyses (Stith and others, 2011; Green and others, 2014; Zajac and others, 2015). The applications to Everglades National Park and the Biscayne Bay coastal area were combined to produce the Biscayne and Southern Everglades Coastal Transport (BISECT) model (Swain and others, 2019), which includes the southern tip of the Florida peninsula. BISECT is being used to examine the dynamics of sea-level rise for the Comprehensive Everglades Restoration Plan (CERP) water-management changes and other structural changes to the hydrodynamic system.

Appraisal of the effects of future climate change on the hydrologic system in south Florida requires projection of future climate and sea-level conditions. The uncertainty in projecting future conditions requires the examination of multiple scenarios and a determination of the sensitivity of the hydrologic system to these uncertainties (Obeysekera and others, 2015). An examination of past conditions and how they compare to recent hydrology also helps to develop an understanding of the dynamics of the system and how hydrology responds to sea level and management changes. In order to use the BISECT model to examine hydrologic factors that affect coastal vegetation change, a hindcast simulation was developed for conditions during the 1926-1932 period (Swain and others, 2015). These results can be compared to the results of the 1996-2004 simulation to determine the effective differences in coastal vegetation habitat factors. The hindcast simulation includes the Great Miami Hurricane of 1926 (GMH), a major storm that ranks as the costliest hurricane in the United States when normalized to inflation and wealth at the national level and changes in population and housing at the coastal county level (Pielke and others, 2008). The characteristics of the GMH must be largely estimated due to lack of historical data, which was also the case for much of the input to the 1926-1932 simulation. 


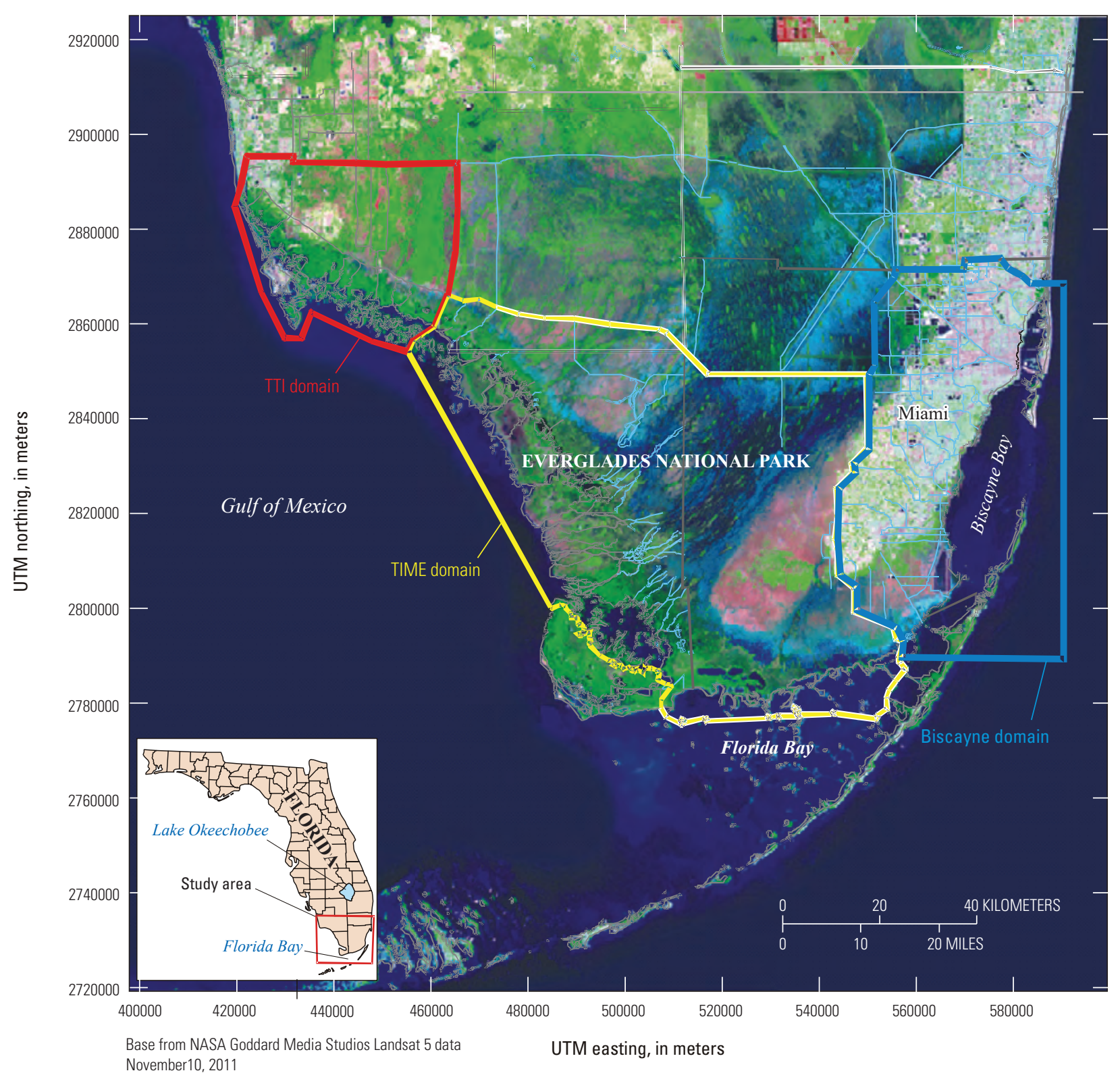

Figure 1. Study area including Everglades National Park (Tides and Inflows of the Mangroves of the Everglades [TIME] model domain), Ten Thousand Islands (TTI model domain), and the eastern coastal area (Biscayne model domain). The Biscayne and TIME simulations were combined into the BISECT simulation.

The hindcast model allowed the long-term effects of the GMH to be examined by incorporating additional scenarios where the effect of the hurricane was removed from the simulation (Swain and others, 2015). The effect of the storm depends on the antecedent hydrologic conditions and the physical features relevant to the coastal surge. Comparing the same storm strike at different historical times can improve understanding of how changes in the system can affect the severity of storm damage.
The purpose of this report is to use numerical simulations of the hydrologic response to historical and hypothesized modern hurricane strikes to determine how historical changes in climate, sea level, coastal topography, and the manmade canal system affect the severity of inundation and salinity intrusion from a major storm. Determining the hypothetical effects of a storm at different points in time is made possible by using numerical hydrologic simulations. An assessment of those effects can determine which historical changes affect the hydrologic response to a particular storm. 


\section{Methods}

A hindcast simulation was previously developed using the BISECT hydrologic model to assess the effects of the GMH. A detailed description of the BISECT model development can be found in Wang and others (2007) and Lohmann and others (2012). The development of the BISECT simulations including the hindcast period and the historical storm representation is described in Swain and others (2015). The repurposing of the hurricane simulation makes use of these simulation tools with further use of historical and recent data to model the effects of the GMH in its historical context. In both the recent and hindcast simulations, the surface features are roughly described on the 500-meter model grid scale, and the resolution of overland flow resistance, infiltration rate, and topography are limited to this scale. The flow in the canal system is not implicitly represented; instead, the water level in the canals is defined by user input for computation of groundwater leakage. The canal system's effect on groundwater is represented along with the associated drainage of the system. The canal levee system, which affects overland flow, is also represented in the topography for the 1996-2004 simulation but is absent in the hindcast period. Coastal canal outflows are likewise defined by the user.

\section{Previous Simulations}

The GMH was represented in the hindcast 1926-1932 period (hereinafter referred to as "hindcast simulation") for the purposes of delineating the longer-term effects of the storm. This simulation period was later extended to the years 1926-1940. Although these later years are not essential to simulating the $\mathrm{GMH}$, this longer simulation is used in this study. The variables of the GMH were developed from several sources; for example, wind field data from Hurricane Wilma in 2005 were used as surrogates for the unknown spatial distribution of wind in the GMH (Swain and others, 2015). The 2005 wind data were also useful to represent a Wilma-type storm strike in a simulation representing the recent period 1996-2004 (hereinafter referred to as "recent simulation"). These simulations were used to compare different parameterizations of the hurricane parameters and a Wilma-type storm replacing the GMH strike (Swain and others, 2015).

The primary differences between the 1926-1940 and 1996-2004 simulations include the change in static parameters and the change in time-series parameters. The static parameters include the canal system (which expanded considerably during the intervening seven decades) and the topography. The only primary canals in place during the entire period 1926-1940 were the Tamiami Canal, Miami Canal, and Snapper Creek Canal along with several shorter coastal canals further south (Renken and others, 2005; fig. 2). The expanded canal system also includes the coastal hydraulic structure discharges to Biscayne Bay, which were not operational in the hindcast simulation period. The unregulated outflows for the 1926-1940 period are represented by the mean flow rates for 1996-2004, the timeframe of the original BISECT model. The differences in topography between the 1926-1940 and 1996-2004 simulations are predominantly along the eastern coast (fig. 2), and these model differences primarily reflect the resetting of coastal elevations in the model near modern canals to predevelopment values. With minimal historical data, no alterations were made in the western part of the study area, but the elevations near coastal canals were altered to match the adjacent model-cell elevations. This leveling process removes the levees and other elevation variations associated with the modern canals.

The time-series variables include tidal levels, surfacewater inflows, rainfall, evapotranspiration (ET), wind, and salinities. The tidal fluctuation is defined by the same frequency components in both the hindcast and recent simulations, but the mean tidal level is changed by the measured sea-level rise difference (Maul and Martin, 1993), which is approximately 18 centimeters $(\mathrm{cm})$. The mean tidal levels computed for 1926 and 1932 are -0.390 meter $(\mathrm{m})$ and $-0.373 \mathrm{~m}$ (North American Vertical Datum of 1988 [NAVD 88]), respectively, compared to a $-0.20-\mathrm{m}$ mean level for 2004. The surface-water inflows occurring along the northern boundary are estimated for the hindcast simulation from a seasonal fit equation to Lake Okeechobee levels (Swain and others, 2015). Rainfall for the hindcast is obtained from two existing gages (Swain and others, 2015), but little specific information is available to define the boundary salinity, wind, and solar radiation (used to calculate ET). The boundary salinities are far enough from the shorelines to be reasonably defined as oceanic average values (Swain and others, 2019) for the recent period, which should be similar to the values for the hindcast period. The wind and solar radiation timeseries in the hindcast period is likely similar in intensity and directional variations to those of the recent period, but the ET rates are affected by land-cover vegetation (reflected as stomatal resistance in ET computations), which has certainly been reduced in the urban areas of this model between the hindcast and recent periods (Swain and others, 2019). There are no specific data for this area to modify stomatal resistance, and the long-term ET rate is less of a factor when analyzing the short-term effects of hurricane strikes; therefore, the stomatal resistance representation is left the same in the recent and hindcast simulations.

\section{Comparisons of Storm Effects in Different Simulation Periods}

The effect of climatic and anthropogenic changes on the impact of storm strikes is examined by simulating the GMH in differing time periods. The hindcast simulation is extended to the 1926-1940 period, and the representation of storm wind, rain, and tidal surge, as refined in the previously published 


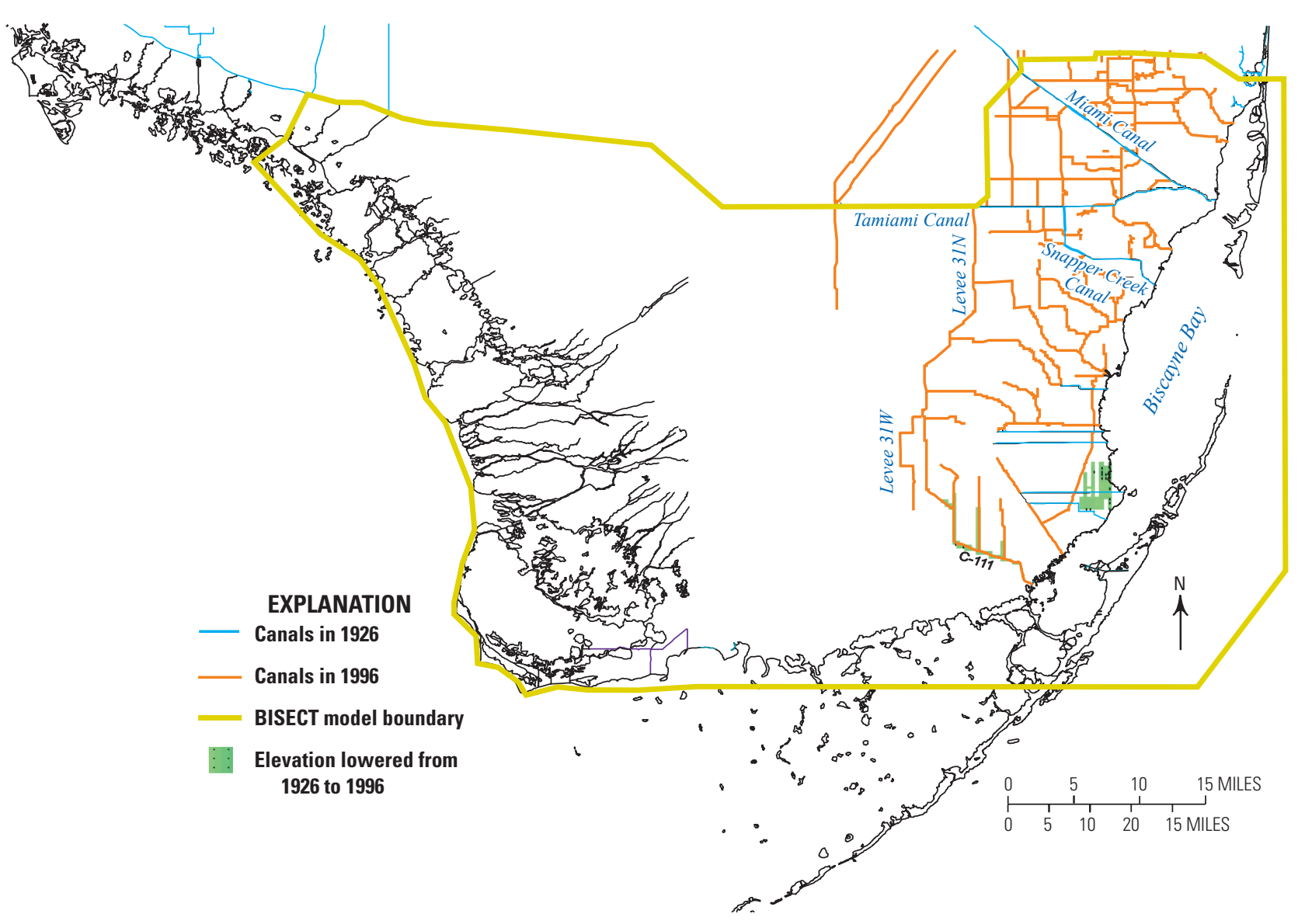

Figure 2. The canal system and topography in the BISECT model area in 1926 and 1996, south Florida.

simulations, is applied on the simulation date September 18 , 1926. The BISECT model datasets are archived online (Swain, 2020).

This simulation of the historical GMH strike is compared with a revised recent simulation that represents the GMH strike on September 18, 1996. With the same storm wind, rain, and tidal surge height above the ambient sea level in both simulation periods, the comparison indicates how the changes to the south Florida coastal system between 1926 and 1996 affect the impact of the same storm. These coastal system changes include sea-level rise, expansion of the canal system and inland water deliveries, topography in the built-up areas, and the timeseries of rainfall. The rainfall over the 1926-1940 period averaged 157.6 centimeters per year $(\mathrm{cm} / \mathrm{yr})$, and the rainfall over the 1996-2004 period averaged $139.6 \mathrm{~cm} / \mathrm{yr}$. To determine which variables affect the hydrologic response of a particular storm, a third simulation was implemented that included all the parameters of the 1926-1940 simulation with the GMH, with the exception of the sea-level timeseries, which was set to the higher 1996-2004 values.

Coastal salinity and surface-water inundation are the most important characteristics of hydrologic response to storms in comparisons between simulation results for the three GMH scenarios: (1) hindcast inland system and hindcast sea level (HH simulation); (2) recent inland system and recent sea level
(RR simulation); and (3) hindcast inland system and recent sea level (HR simulation). Three coastal areas in the southeastern coastal model domain were chosen for evaluation of salinity and inundation (fig. 3). From north to south, area A includes most of the coastal control structures in southern MiamiDade County in the recent period and, therefore, changes the most hydrologically between the hindcast and recent periods. Area B includes fewer control structures and has lower land elevations than area $\mathrm{A}$. The southernmost area, C, contains the smallest inland portion of the three areas, includes the southernmost shoreline of Biscayne Bay, and contains parts of the offshore barrier islands.

\section{Results}

A comparison between the HH, RR, and HR simulations on the day before and the day after the hurricane strike indicates that inundation differences were minimal, even if the amount of storm-surge flooding was substantial. The inland extent of salinity increased substantially more in the RR and HR simulations than in the HH simulation, especially in area A (fig. 3). The salinity intrusion pattern was also similar in $\mathrm{RR}$ and $\mathrm{HR}$, where the additional intrusion is most obvious 

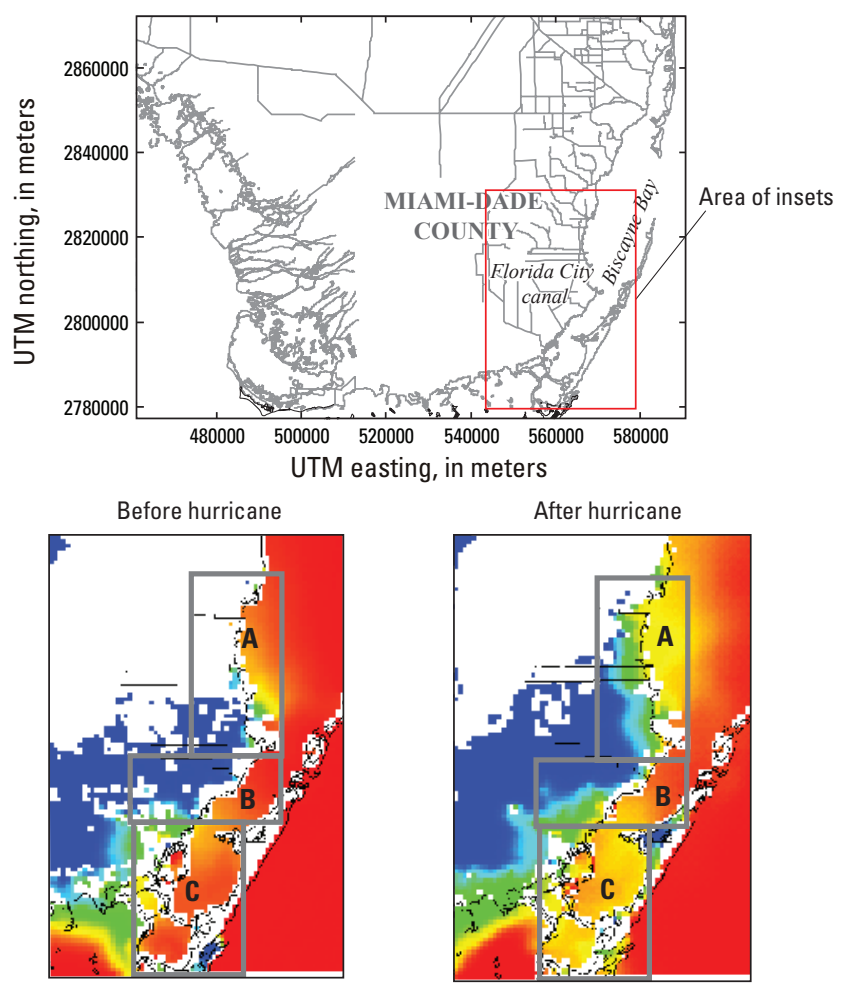

Great Miami hurricane, 1926- $\mathrm{HH}$
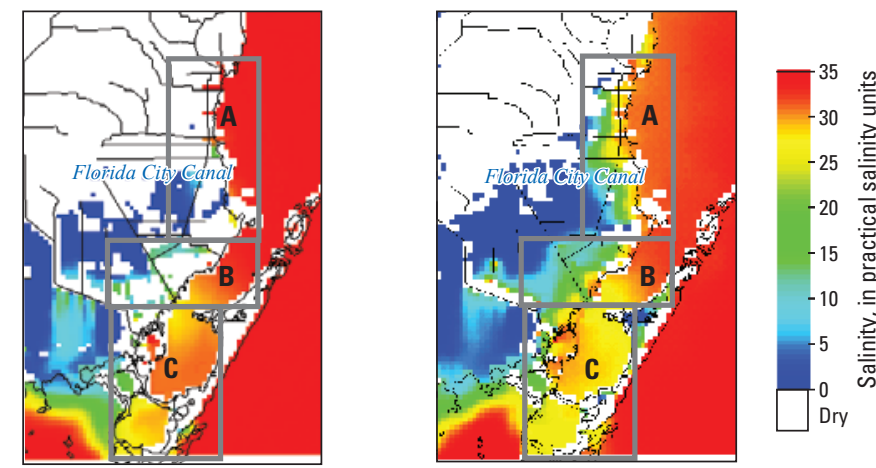

Great Miami hurricane, 1996-RR
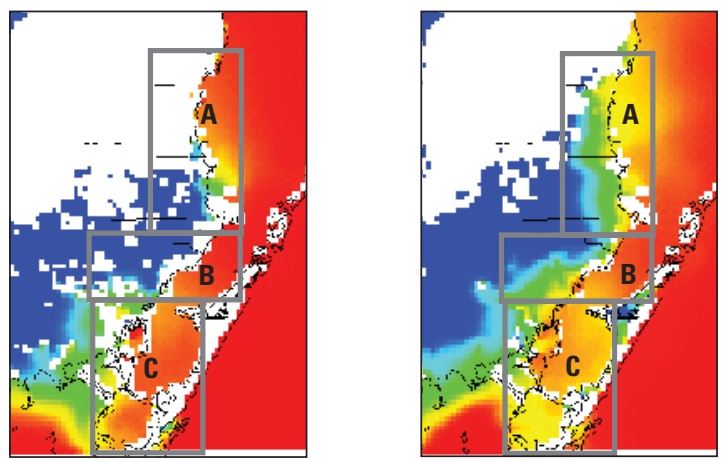

Great Miami hurricane, 1926, with modern sea level-HR

Figure 3. Salinity and inundation in areas $A, B$, and $C$ before and after the hindcast inland system and hindcast sea-level (HH) simulation; recent inland system and recent sea-level (RR) simulation; and hindcast inland system and recent sea-level (HR) simulation, south Florida. in locations south of Florida City Canal (south part of area A; fig. 3). In area B, the post-hurricane salinity patterns are affected by the canals in the RR simulation, but HR still shows more salinity intrusion in the northern part of area $\mathrm{B}$ than the HH simulation. Higher sea level alone allows distinctly more salinity intrusion in the HR simulation than in the $\mathrm{HH}$ simulation.

Quantifying the simulated changes in the extent of inundation, inland salinity, and offshore salinity in response to these storm scenarios yields more extensive insight (table 1 and fig. 4). Comparisons in the three areas delineated (A, B, and $\mathrm{C}$ ) in figure 3 indicate that, in areas $\mathrm{A}$ and $\mathrm{B}$, the increase in inundation was greatest in the RR simulation, with a difference of more than 18 square kilometers $\left(\mathrm{km}^{2}\right)$ between scenarios HR and RR in area B (table 1). However, as can be seen in figure 4, the RR simulation starts with a lower prehurricane inundation in area B than the other simulations. In area $\mathrm{C}$, the increase in inundation was similar in all three simulations.

Increases in mean inland salinity in all areas due to the hurricane strike were 1.3 to 4.0 practical salinity units (PSU) higher in the RR and HR simulations than in the $\mathrm{HH}$ simulation (table 1). Comparing pre- and post-hurricane inland salinities (fig. 4) illustrates the similarity of the RR and $\mathrm{HR}$ responses to the hurricane in contrast to the $\mathrm{HH}$ simulation, indicating that mean sea level is a prominent factor when a hurricane moves salinity ashore. In general, small decreases in offshore salinity are indicated in all scenarios, do not demonstrate any distinctive patterns, and are likely related to rainfall runoff. 
Table 1. Changes in inundation and salinity in three areas before and after the simulated Great Miami Hurricane of 1926, south Florida.

$\left[\mathrm{km}^{2}\right.$, square kilometers; PSU, practical salinity units, HH, hindcast inland system and hindcast sea level; RR, recent inland system and recent sea level; HR, hindcast inland system and recent sea level]

\begin{tabular}{|c|c|c|c|}
\hline \multirow[b]{2}{*}{ Simulation } & \multicolumn{3}{|c|}{ Area A } \\
\hline & $\begin{array}{l}\text { Inundation } \\
\text { change }\left(\mathbf{k m}^{2}\right)\end{array}$ & $\begin{array}{l}\text { Inland salinity change } \\
\text { (PSU) }\end{array}$ & $\begin{array}{l}\text { Offshore salinity change } \\
\text { (PSU) }\end{array}$ \\
\hline Great Miami Hurricane in 1996 (RR) & 86.00 & 8.23 & -2.41 \\
\hline Great Miami Hurricane in 1926 with 1996 sea level (HR) & 77.25 & 8.05 & -0.89 \\
\hline Great Miami Hurricane in $1926(\mathrm{HH})$ & 37.50 & 4.01 & -0.29 \\
\hline Great Miami Hurricane in 1996 (RR) & 59.50 & 8.05 & -1.84 \\
\hline \multirow[t]{2}{*}{ Great Miami Hurricane in 1926 with 1996 sea level (HR) } & 41.25 & 7.14 & 0.05 \\
\hline & \multicolumn{3}{|c|}{ Area C } \\
\hline Great Miami Hurricane in $1926(\mathrm{HH})$ & 54.75 & 5.95 & -1.47 \\
\hline Great Miami Hurricane in 1996 (RR) & 51.00 & 7.23 & -0.53 \\
\hline Great Miami Hurricane in 1926 with 1996 sea level (HR) & 51.25 & 7.45 & -1.05 \\
\hline
\end{tabular}

\section{Discussion}

The simulated changes in inundation and salinity can be used to draw several conclusions about the relations between long-term changes to the coastal hydrologic system during the entire 1926-1996 period and major storm impacts. The inundation change the day after the storm strike is not highly sensitive to the represented changes in the hydrologic system; however, the largest inundation increase for areas A and $\mathrm{B}$ is in the RR simulation (table 1) with its recent sea level. Simulation $\mathrm{HH}$ has less prehurricane inundation in area $\mathrm{C}$ than the RR and HR simulations (fig. 4), and therefore has a slightly larger inundation increase. However, the inland salinity data demonstrate differences between the three different simulations more clearly than the inundation data. The purpose of the HR simulation is to isolate the effects of mean sea-level changes by representing all 1926-1940 conditions except for the 1996-2004 sea level. The hurricane in the RR and HR simulations brings more salinity ashore than in the $\mathrm{HH}$ simulation, indicating that the primary factor affecting the difference in salinity between the three different simulations of the storm strike is the rise in sea level from the 1926-1940 period to the 1996-2004 period. The simulated hydrologic differences between the 1926-1940 and 1996-2004 periodsincluding expansion of the canal system, differences in inland water deliveries, topographic changes in the built-up areas, and differences in rainfall-have less of an effect on hurricaneinduced salinity intrusion than changes in mean sea level.
These results derived from the simulations are intuitively reasonable because the hydrologic differences, other than sea level, are not likely to strongly affect the inland intrusion of salinity from a short-term storm event. The results do suggest, however, that any mitigation efforts against increased storm surge effects due to sea-level rise would have to be far more substantial than any previous structural changes.

\section{Model Limitations}

In addition to the inherent limitations in the FTLOADDS code and the BISECT application of the code (Swain and others, 2019), several features of the specific storm representation limit the certainty of the solutions and conclusions.

1. Storm surge is approximated as a defined height above sea level, and the full fetch of the surge buildup is not well represented.

2. The flow in the canal system is not represented, and the water level in the canals is defined by user input. Coastal canal outflows are likewise user defined.

3. The surface features are roughly described on a 500-m grid scale, and the resistance to overland flow, infiltration rate, and small-scale topography are either estimated or below the resolution of the model.

Neither frictional resistance nor infiltration is changed between simulated 1926 and 1996 conditions, and only topography around canals is altered, as described previously. Although 
Area A
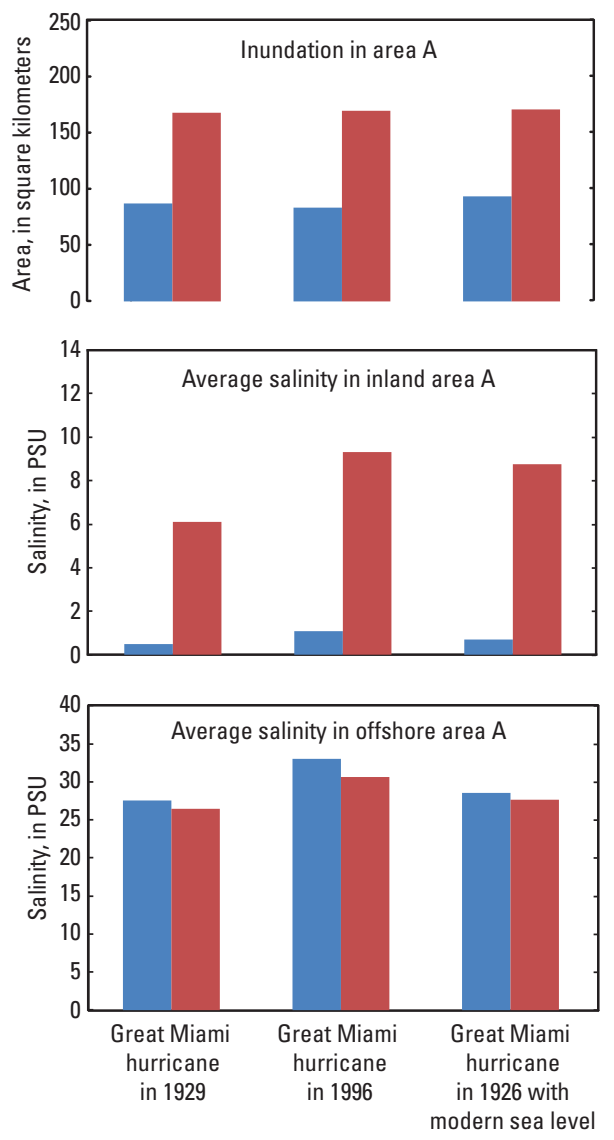

Area B

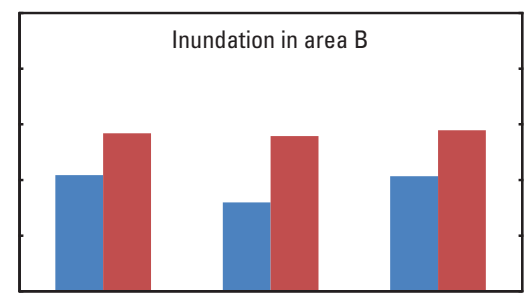

Average salinity in inland area $B$
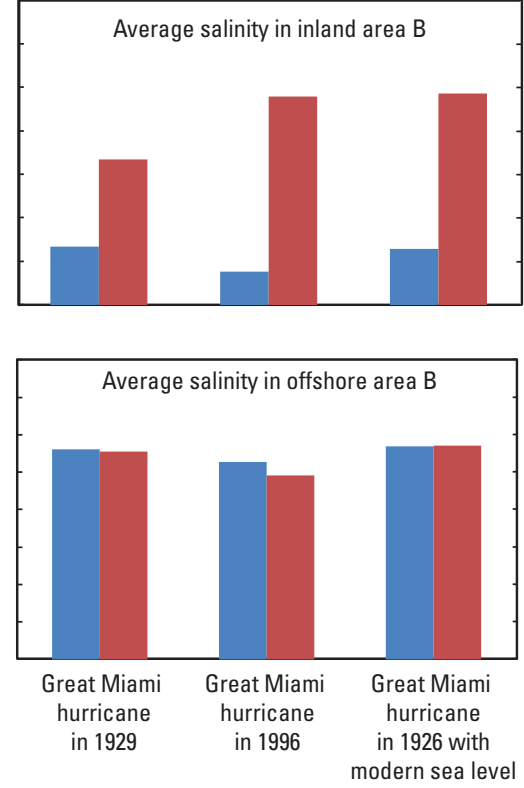

Area C
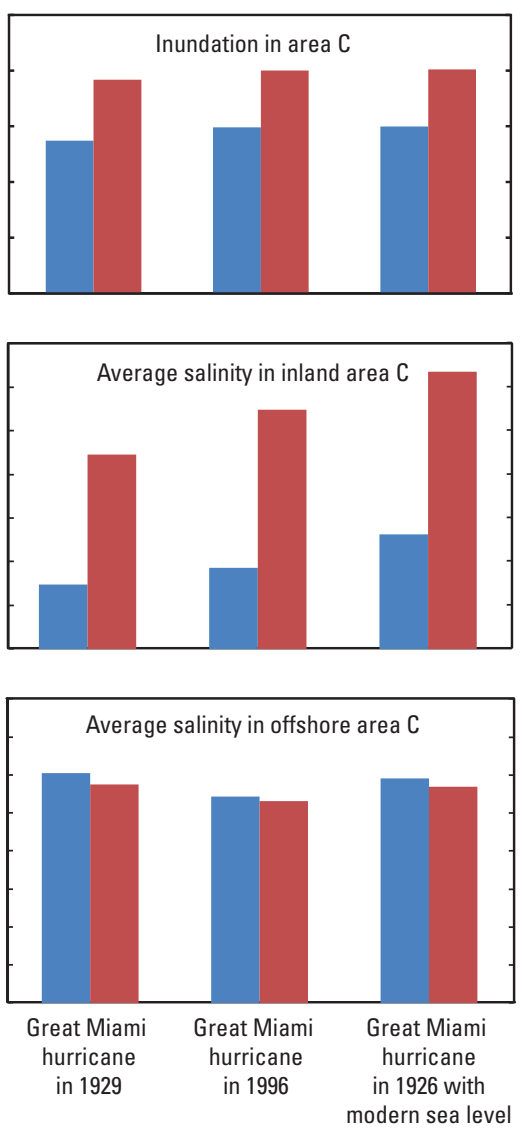

EXPLANATION

Before hurricane

After hurricane

Figure 4. Inundation and salinity before and after the simulated Great Miami Hurricane of 1926, south Florida. [HH, hindcast inland system and hindcast sea level; RR, recent inland system and recent sea level; HR, hindcast inland system and recent sea level; PSU, practical salinity units; see fig. 3 for locations of areas $A, B$, and $C$ ]

limited by these factors, the usefulness of the simulations is enhanced by the comparative nature of the results. Computing differences between two scenarios allows equivalent model errors in the scenarios to cancel each other out, which should indicate general trends more accurately.

The simulation results can be expanded temporally to examine other storm configurations at different historical times and better parameterize the relations between particular storms, time periods, sea-level rise, and storm effects. By specifying the configuration of the storm, a more quantitative result can be obtained, and the simulated storms can be rated and compared with the suite of known hurricane landfalls. In addition, actual and proposed water-management strategies can be applied to the model to better determine their relative impacts.

Sufficient information exists to approximate likelihoods of hurricane strikes of particular intensities, and this information can be coupled with the inundation and salinity simulations for a range of conditions. These efforts can produce a predictive tool to estimate future storm effects and the implications of anthropogenic changes.

\section{Summary}

A coupled hydrodynamic surface-water/groundwater model was used to simulate the hydrologic effects of the 1926 Great Miami Hurricane (GMH) in a hindcast simulation for the period 1926-1940. The storm surge, wind field, and rainfall from the GMH storm were also hypothesized to have occurred in 1996, as part of a simulation of hydrologic conditions during 1996-2004 for which the canal-system layout, topography, water deliveries, and antecedent climatic conditions were markedly different than existed during the 1926 
GMH. Model results indicate that substantially more surfacewater salinity would have been brought ashore in the recent period than in the hindcast period.

A simulation of the effects of the hurricane strike was made under 1926 conditions with one difference-sea level was assumed to be at 1996 levels. The purpose of this simulation was to isolate the effect of sea-level change on the response of the hydrologic system to a powerful hurricane strike. The resulting pattern of surface-water salinity intrusion was similar to that of the 1996 simulated storm and indicates that sea-level rise between the hindcast and recent periods is the primary factor affecting salinity intrusion in the recent simulation. Moreover, the structural changes in the inland system, including canal-system design, topography, and water deliveries, did not substantially affect or mitigate the effects of sea level on the storm impacts.

\section{Acknowledgments}

The authors would like to thank the USGS Southeast Region for funding support that allowed us to continue our research to develop more insight into the hydrologic system.

\section{References}

Green, T.W., Slone, D.H., Swain, E.D., Cherkiss, M.S., Lohmann, M.A., Mazzotti, F.J., and Rice, K.G., 2014, Evaluating effects of Everglades restoration on American crocodile populations in South Florida using a spatiallyexplicit, stage-based population model: Wetlands, v. 34, no. S1, suppl. 1, p. 213-224, accessed March 3, 2017, at https://doi.org/10.1007/s13157-012-0370-0.

Langevin, C.D., Swain, E.D., and Wolfert, M.A., 2005, Simulation of integrated surface-water/ground-water flow and salinity for a coastal wetland and adjacent estuary: Journal of Hydrology (Amsterdam), v. 314, no. 1-4, p. 212-234. [Also available at https://doi.org/10.1016/ j.jhydrol.2005.04.015.]

Lohmann, M.A., Swain, E.D., Wang, J.D., and Dixon, J., 2012, Evaluation of effects of changes in canal management and precipitation patterns on salinity in Biscayne Bay, Florida, using an integrated surface-water/groundwater model: U.S. Geological Survey Scientific Investigations Report 2012-5099, 94 p. [Also available at https://doi.org/ 10.3133/sir20125099.]

Maul, G.A., and Martin, D.M., 1993, Sea level rise at Key West, Florida, 1846-1992-America's longest instrument record?: Geophysical Research Letters, v. 20, no. 18, p. 1955-1958, accessed March 3, 2017, at https://doi.org/ 10.1029/93GL02371.
Mitchell, C.L., 1926, The West Indian hurricane of September 14-22, 1926: Monthly Weather Review, no. 10, p. 409-414.

Obeysekera, J., Barnes, J., and Nungesser, M., 2015, Climate sensitivity runs and regional hydrologic modeling for predicting the response of the greater Florida Everglades ecosystem to climate change: Environmental Management, v. 55, no. 4, p. 749-762. [Also available at https://doi.org/ 10.1007/s00267-014-0315-x.]

Pielke, R.A., Jr., Gratz, J., Landsea, C.W., Collins, D., Saunders, M.A., and Musulin, R., 2008, Normalized hurricane damages in the United States: 1900-2005: Natural Hazards Review, v. 9, no. 1, p. 29-42. [Also available at https://doi.org/10.1061/(ASCE)1527-6988(2008)9:1(29).]

Renken, R.A., Dixon, J., Koehmstedt, J., Ishman, S., Lietz, A.C., Marella, R.L., Telis, P., Rodgers, J., and Memberg, S., 2005, Impact of anthropogenic development on coastal ground-water hydrology in southeastern Florida, 1900-2000: U.S. Geological Survey Circular 1275, 77 p. [Also available at https://doi.org/10.3133/cir1275.]

Stith, B.M., Reid, J.P., Langtimm, C.A., Swain, E.D., Doyle, T.J., Slone, D.H., Decker, J.D., and Soderqvist, L.E., 2011, Temperature inverted haloclines provide winter warmwater refugia for manatees in southwest Florida: Estuaries and Coasts, v. 34, no. 1, p. 106-119. [Also available at https://doi.org/10.1007/s12237-010-9286-1.]

Swain, E.D., 2020, FTLOADDS (combined SWIFT2D surface-water model and SEAWAT groundwater model) simulator used to repurpose a hindcast simulation of the 1926 Great Miami Hurricane using the south Florida peninsula for the Biscayne and Southern Everglades Coastal Transport (BISECT) model: U.S. Geological Survey data release, https://doi.org/10.5066/P9C681IV.

Swain, E.D., and Decker, J.D., 2009, Development, testing, and application of a coupled hydrodynamic surface-water/ groundwater model (FTLOADDS) with heat and salinity transport in the Ten Thousand Islands/Picayune Strand Restoration Project area, Florida: U.S. Geological Survey Scientific Investigations Report 2009-5146, 42 p. [Also available at https://doi.org/10.3133/sir20095146.]

Swain, E.D., Krohn, D., and Langtimm, C.A., 2015, Numerical computation of hurricane effects on historic coastal hydrology in Southern Florida: Ecological Processes, v. 4, no. 4, p. 1-20, accessed March 7, 2017, at https://doi.org/ 10.1186/s13717-014-0028-3.

Swain, E.D., Lohmann, M.A., and Goodwin, C.R., 2019, The hydrologic system of the south Florida peninsula-Development and application of the Biscayne and Southern Everglades Coastal Transport (BISECT) model: U.S. Geological Survey Scientific Investigations Report 2019-5045, 114 p. [Also available at https://doi.org/10.3133/sir20195045.] 
Wang, J.D., Swain, E.D., Wolfert, M.A., Langevin, C.D., James, D.E., and Telis, P.A., 2007, Applications of FTLOADDS to simulate flow, salinity, and surface-water stage in the Southern Everglades, Florida: U.S. Geological Survey Scientific Investigations Report 2007-5010, 112 p. [Also available at https://doi.org/10.3133/sir20075010.]
Zajac, Z., Stith, B., Bowling, A.C., Langtimm, C.A., and Swain, E.D., 2015, Evaluation of habitat suitability index models by global sensitivity and uncertainty analyses-A case study for submerged aquatic vegetation: Ecology and Evolution, v. 5, no. 13, p. 2503-2517. [Also available at https://doi.org/10.1002/ece3.1520.]

For more information about this publication, contact Director, Caribbean-Florida Water Science Center U.S. Geological Survey 4446 Pet Lane, Suite 108 Lutz, FL 33559

For additional information, visit https://www.usgs.gov/centers/car-fl-water 




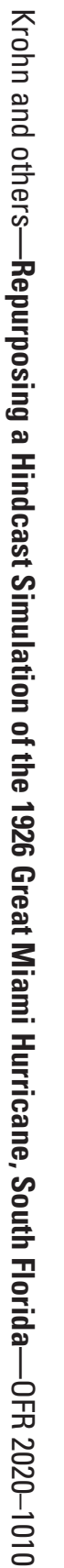

